\title{
Geotechnical Investigation of Soil around Mbaukwu Gully Erosion Sites, South-Eastern Part of Nigeria.
}

\author{
${ }^{1}$ Chikwelu E. E.And ${ }^{2}$ Ogbuagu F. U. \\ ${ }^{I}$ Department of Physics Education, Federal College of Education (Tech), Umunze, Anambra State. \\ ${ }^{2}$ Department of Civil Engineering, Federal Polytechnic Oko, Anambra State.
}

\begin{abstract}
An assessment of the geotechnical parameter in the formation of gullies in high risk erosion areas such as Mbaukwu town of south-eastern Nigeria is presented. The soil around the Mbaukwu gully erosion sites were investigated by collecting samples from the gully channels and excavation trial pits. The trial pits depth ranges between 0-1.0m and 0-1.5m, also samples were collected at depths of 35, 60, and 62m along the gully channels. Eight disturbed and undisturbed samples were collected and analyzed. Sieve analysis, Atterberg limits and Compaction tests were carried out on the selected soil samples. The soils are generally not uniform even though similarities exist between some. The liquid limit ranges from 32.00 to 46.00 and has a mean of 35.95. The Plastic Limit ranges from 17.50 to 28.10 and has a mean of 21.15. The Plasticity Index ranges from 10.50 to 20.00 and has a mean of 14.80. The Maximum Dry Density (MDD) ranges from 2.001 to 3.910 and has a mean of 2.490. The Optimum Moisture Content (OMC) ranges from 7.90 to 11.00 and has a mean of 8.980.Result of geotechnical investigation and laboratory analysis showed that the soil in the study area is majorly loose sand. They contain very small amount of clay which serves as a binding material. The lithology of the area is dominated by sandstone with very little binding material and is one of the chief reasons for the high intensity of the gullies in the area. The maximum dry density values are generally low which indicates that the soils are unconsolidated and friable. Enlightenment and awareness of erosion control should include land use habits of the people in their agricultural practices and care of vegetation. Concrete terracing of gully affected areas is recommended to reduce the impact or the force of rain-drop. This will restrict the widening of incipient gullies. Holistic rehabilitation development programs of monitoring the earth surface to reclaim devastated land as well as to ensure a safe environment should be encouraged.
\end{abstract}

Keywords: geotechnical properties gully erosion, maximum dry density, optimum moisture content, Mbaukwu.

\section{Introduction}

Soil is one of the most vital earth's natural resources. It sustains both plant and animal for their growth and development since it shelters most valuable earth resources. Therefore, threats to the soil poses danger to both human and animal life. Erosion is one of the most fatal threats and hazard to the environment. It constitutes a clear form of soil degradation and destruction. It occurs where surface water flow has become trapped in a small concentrated stream, and begins to erode channels in the ground surface, making it wider and deeper.

According to United Nation's (UN) convention to combat land degradation (CCD), soil erosion automatically results in the reduction or loss of biological and economic productivity of terrestrial ecosystem, including soil nutrients, vegetation, other biota and the ecological processes that operates therein, (Canter, 2004), avows that by the year 2020, soil erosion may pose a serious threat to food production and rural development as well as, urban livelihoods, particularly in poor and densely populated areas of the developing world. The effect of erosion on structures, natural resources and foundations is of great concern to the environmental and engineering geologists.

In particular, Mbaukwu, Agulu and most other towns in Anambra state have witnessed a massive reduction and unavailability of land for agricultural and other purposes as a result of erosion. The occupants of these areas of land are forced to learn how to cope with gully erosion problem since the rate of its occurrence is faster than the rate at which solutions are being provided. This cankerworm on the soil is known to be ignited by factors such as: land slope, amount of space, percentage of water that infiltrates the ground, the amount available as run-off and geotechnical properties of the soil in the environment.

\section{Mechanisms Of Gully Development}

In explaining the mechanisms of gully development in southeastern Nigeria, most workers stress the importance of the deeply weathered bedrock exposed by the removal of vegetation cover , and the impact of heavy rainfall and the associated flood on such rocks /soils (Ofomata, 1965;Nwajide and Hoque, 1979). The role of seepage forces due to groundwater fluxes at the gullies have also been highlighted (Uma and Onuoha, 1987); the general consensus is that the high intensity rainfall in the areas affected produces high volumes of overland 
flows with high erosive energy. The action of the high erosive floods on the highly susceptible geologic/soil materials produce the complex gullies.

Field studies reveal that the initial stage in the gully development process is the concentration of storm water in small channels such channels may be natural or could be man made in the form of foot-paths, cattle trails, or even vehicle tires, (Egboka, and Okpoko, 1984). Flood water cuts the sides and bottom of the channels extremely rapidly, and the initial $\mathrm{v}$ - shape channel soon becomes semi-circular with almost vertical banks and flat bottom. Further undercutting leads to over steepening and consequent collapse of the gully walls. Gully wall failure is also aided by seepage forces at the toe of the walls; especially in gully wall failure is also aided by seepage forces due to near critical hydraulic gradients at the various levels of seepage on some gully walls. These high and vertically directed seepage fluxes produce boiling conditions, piping and internal erosion that undermine the base of gullies, leading to large-scale landslides'. Land sliding arising from the instability of the gully slopes is known to be the principal mechanism of gulling in the places where the hazard has been experienced most (e.g. Agulu-Nanka, Oko, Amucha, Abiriba-Ohafia, etc).

\section{Mitigation Measures Against Erosion/Gullying Hazards In Nigeria}

Measures so far adopted to check the erosion menace in southeastern Nigeria have contributed to reducing the erosive capacity of the flood water and /or increasing the erosion resistance of the soil /geologic materials. Protective measures adopted so far fall into two categories. The first consists of a network of hydraulic regulation structures and drainage galleries that drain off run-offs from areas adjacent to the gully heads, and discharge them in stabilized areas where erosion is not expected to occur. It also include a network of check dams and fences in area that are prone to gulling .These reduce the erosive energy of flood waters .The second category of mitigation measures consists of intensive reforestation of affected areas and consolidation works to stabilize the soil/geologic materials and encourage more infiltration of rainwater, Onuoha, and Uma, (2008).

The results of the measures so far taken have been varied in some gully sports (e.g. those at Oraukwu, Alor, Awgbu and Mbaukwu),

The reduction of flood volume and velocity has apparently stabilized the gullies. However, in the most dangerous spots (e.g. Mbaukwu, Agulu-Nanka, Oko, etc) sliding and slumping have continued unabated despite these measures. Earlier protective measures involving check dams, infiltration pits, etc. also failed to check the advance of the gullies. This was probably because the design of the mitigation measures did not take into consideration all the elements involved in the gulling process. In Oko and Nanka for example, the major mechanism of gully is land sliding which is triggered off by the undermining of gully bases by piping, internal erosion and boiling conditions, hydraulic gradients at the gully bases. Since the existing protective measures were designed to force more infiltration of rain water into the ground at the gully heads, rather than checking them, they helped to accelerate gully development through greater fluxes of groundwater. Based on this revelation, Uma and Onuoha (2008) advocated measures involving the permanent dewatering of the gully slopes and lowering of the groundwater levels in the vicinity of the gullies.

These involve the use of subsurface horizontal drains, drainage galleries, well point systems, or intensive groundwater abstraction through deeper boreholes.

Erosion problems in Nigeria cannot be checked overnight, especially these days when the country is facing severe problems. The attention of the authorities is usually drawn to a ravaged area only when the effects of erosion and gulling have assumed catastrophic proportions. This approach has to stop, while a proper assessment of the risk has to be made across the country. The effects of rainfall, ground water fluxes, water chemistry and soil properties on erosion and gulling have to be properly studied and understood. This is the only way successful mitigation and control measures can be adopted, Onuoha, and Uma, (2008).

\section{Geology Of The Study Area.}

The Study area is situated in the central part of Anambra State, Awka- South L.G.A. Anambra State lies within Anambra Basin, the first region where intensive oil exploration was carried out in Nigeria. The Nigeria sedimentary basin includes; Chad/Borno (North-Eastern Nigeria) Sokoto Basin (North-Western Nigeria), Benue Trough and Bida Basin, Anambra Basin, Dahomey (Benin Basin), and Niger Delta Basin. These entire basins are composed of different lithologies, formed at different times and have different mechanisms responsible for their formation. All the basins consist of one or more mineral resources (industrial, metallic and energy of fossil fuels) that are being exploited for national development.

Anambra basin has about $6,000 \mathrm{~m}$ thick of sedimentary rocks. The rocks of the Basin starts with Nkporo shale, Ajalli sandstone, Nsukka Formation, Imo shale, Ameki sand, Ogwashi-Asaba Formation and Benin Formation. Imo shale is a sequence of grey shales, occasionally clay iron stones and sandstones beds, (Trunswell and Cope, 1963) as illustrated in table 1. 
Table 1: Generalized stratigraphic section in the Anambra Basin.

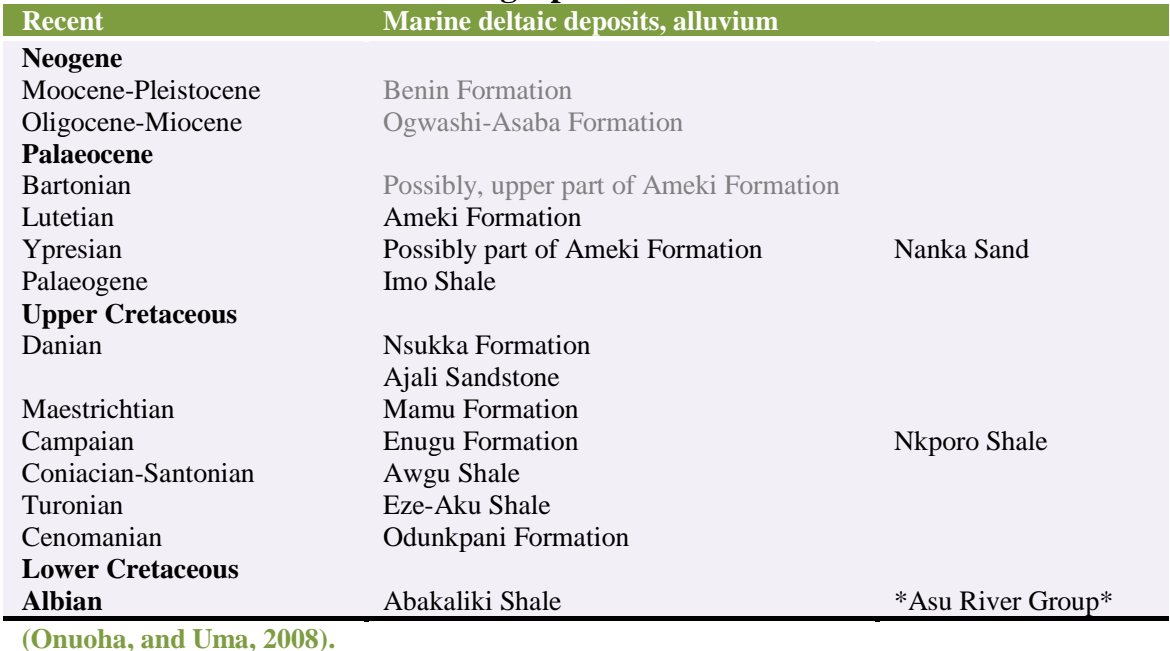

(Onuoha, and Uma, 2008)

The study focuses on Ameki Formation which underlies the study area. Ameki Formation has its lateral equivalence as Nanka sand. The lithology sequence exposed in the area "Mbaukwu" was laid down in the Eocene. This lithology includes sandstone, calcareous shale and shelly limestone in thin bands. Outcrops of the sandstone occur at various places on the higher Cuesta, such as Abagana and Nsugbe, where they are quarried for construction purpose, while the Nanka sands outcrops mainly at Nanka, Oko and Mbaukwu. Lignite was deposited in the Oligocene to Miocene, and it alternates with gritty clay in places. Outcrops of lignite occur in Onitsha and Nnewi. The latest of the four geologic formations is the Benin formation or the coastal plain sands that were deposited from Miocene to Pleistocene.

The Benin formation consists of yellow and white sands. The formation underlies much of Ihiala Local Government Area. Thick deposits of alluvium were laid down in the western parts of the state, south and north of Onitsha in the Niger and Anambra river flood plain. Fig 1 shows the geologic map of the study area, while fig 11 shows the general geological map of the Nigeria. These geologic maps show that the entire area is of sedimentary terrain.

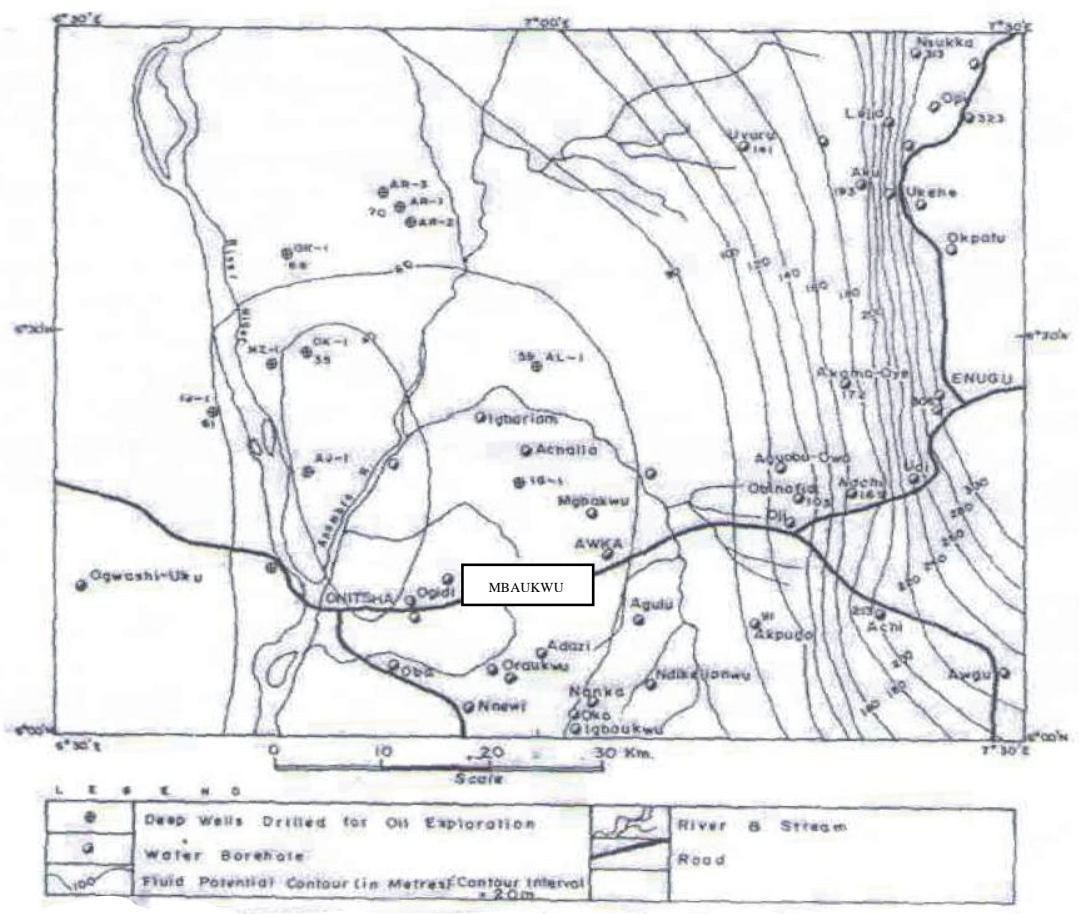

Fig 1: Geologic map of the study area (Onuoha K., M. 2008) 


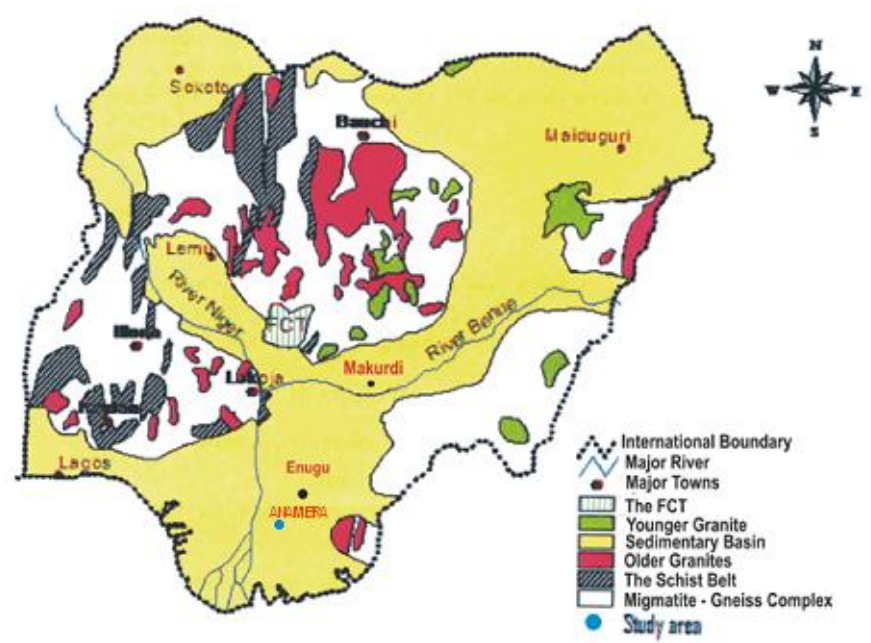

Fig II: General Geologic Map of Nigeria showing the study area.

\section{Hydrogeology}

The hydrogeology of the area depend greatly on the lithology of the area, amount of rainfall water availability for ground water recharge, streams and river channels that run across the study area like "River Azukobo" present in one of the gullies in the study area. The area has a good surface and ground water potential. The sand present in the area is Nanka- sands which is also present in all part of the study area. It is the major problem in accessing groundwater rules in the area in over $80 \%$ of sedimentary terrains, finding groundwater is sure due to efficient networking of pore spaces (both in the porosity \& permeability) but the sand is known to have excessive permeability, thus requiring depths sometimes up to $100 \mathrm{~m}$ like a well dug in Port Harcourt (Akudinobi, 2008) and as a result discourages groundwater exploration because of the great cost involved. Fig 111 shows the hydrogeological map of the study area.

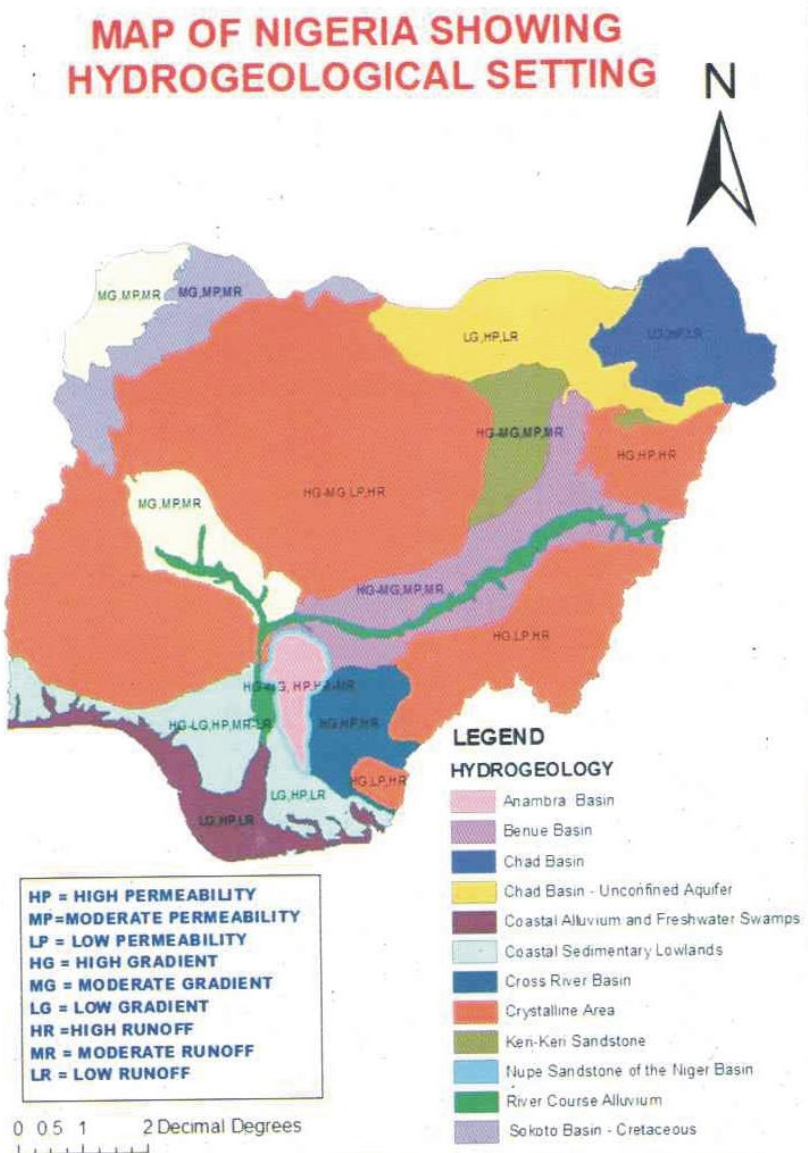

Fig III: The hydro-geological map of the study area. 
Soils

The type and nature of bedrock to a large extent influence the soil developed upon it. The soils of the Anambra Basin belong to the interior zone of laterite soil. The bedrock varies from shale to limestone, marls as well as sandstones and unconsolidated to semi-consolidated sands. The soils are inherently clayey to sandy, having developed on one or the other of the dominantly mud rock or dominantly sandy formations. They have varying degrees of indurations. Sometimes the soils are as a result of deposition of highly ferruginous laterites reworked from older laterites. They are dominantly associated with easily leached and mobile alkalis $\mathrm{Na}, \mathrm{K}, \mathrm{Ca}$. They have less of less mobile elements $\mathrm{Al}, \mathrm{Si}$, and Fe (Nwajide, 2003)

\section{Materials And Methods}

Geotechnical investigation were carried out which include field and laboratory studies. Eight distributed samples were taken for laboratory analysis. The laboratory procedure includes both index and performance test. The laboratory tests were conducted at the Civil engineering laboratory of Construction Company that is domicile in Nigeria and were all performed in accordance with the specified standard procedures (BS 1981, ASTM 1979).

\section{Atterberg or Consistency limited test}

The Atterberg or consistency limited test determines that moisture content at which the soil will flow under its own height. It defines the boundaries of several state of consistency of plastic soil. It is used to determine the plasticity of soil. Atterberg limit test is used in determining the following parameters: liquid limit, plastic limit, plasticity index, liquidity index and relative consistency. Plastic limit is the percentage moisture at which a soil can be rolled without breaking into threats $(3 \mathrm{~mm})$ millimeter in diameter. These parameters help to determine the plasticity and clay content of a soil sample.

Equipment Used: The materials and equipment proposed to be used include; the liquid limit (cassagraude) apparatus, moister and pistil on an oven, a grooving tool, glass plate, a balance for weighing water and some numbered specimen containers.

Liquid Limit Test; It is the moisture content at which the soil begins to behave like fluid under the influence of a standard blows. A portion of the paste was remolded on a glass pattern and laced in the liquid limit apparatus and grooved using a standard grooving tools while preventing air trapped. A sample of the material was then taken in a specimen container and weighed, placed in the oven for $24 \mathrm{hrs}$ and weighed again to determine the moisture content. The procedure is repeated trice again, each time adding little quantity of water. The results were presented in a lab reporting sheet and plotted on a graph paper (moisture content \% against no of blows) and the best straight line drawn between the paints. The moisture content at twenty five blows defines the liquid limit.

\section{Plastic Limit:}

The plastic limit test has a similar procedure like the liquid limit test, except the absence of the liquid limit apparatus. The following apparatus are used: A flat glass plate, spatula, distilled water, containers for incubation, containers for oven drying and an incubator. The soil paste at different moisture contents was rolled with the palm on a glass platen into threats. The threats were put into containers like those in the limit test and weighed. They were then place in the oven for twenty four hours after which they reweighed and the weight difference gave the plastic limit. The results of the two test were analyzed and the plasticity index (PI) was obtained as the numerical difference between the liquid limit (LL) and plastic limit (PL) as PT=LL-PL

\section{Compaction Test:}

Compaction test is carried out with the aim of determining the moisture density relationships of the soil. It is used to determine the maximum bulk density at which the soil can be compacted given specified compaction energy. This test is used primarily to provide field control for earth works where typical specifications will require that soil can be compacted at least a certain percentage of maximum density obtained in a compaction test.

The following apparatus are used for this test, a cylindrical metal mould with effective weight of $2450 \mathrm{~mm}$ and volume $1014 \mathrm{~cm} 3,2.5 \mathrm{~kg}$ metal rammer, cylinder for measuring water, metal tray for mixing, tray for collecting weighted samples, electronic weighing machine, grease for oiling and cleaning rammer, hand towels for mixing, two iron slab red-like scrappers for cutting surface of when compacted into mould, chisel, scoop, hammer, and a container for collecting samples to oven dry. The one point method was used.

$3000 \mathrm{~g}$ of each sample was collected with the aid of the weighing balance and then poured into a pan. It was then poured into a mixing tray and $4 \%$ water as measured using the $1000 \mathrm{ml}$ cylinder and poured into the sample in the mixing tray. The sample was thoroughly mixed and put into the mould in three different layers and was compacted using the rammer (61 times per every layer) after the third layer compaction, the compacted 
sample plus mould was weighed and recorded. This was poured back into the mixing tray and remixed with an additional amount of water (6\%) for this and then compacted again. It is repeated the value of sample plus mould weight began to drop and was usually after five times. After each stage of the compaction process, some amount of the sample was collected and put into some small container ready for oven drying. The numbers on the containers was recorded as well as the weight of the container plus sample (wet weight). The samples in the container were then oven-dried for 24 hours. They were brought out, re-weighed and recorded as (dry weight). The difference between the wet weight and dry weight was calculated and recorded as the average moisture content to determine the maximum density (MDD) and optimum moisture content (OMC) was read off in the graph at the peak point.

Plasticity Index: This is the difference between liquid limit (LL) and plastic limit (PL) PI=LL-PL. The plasticity index represents the range of soil moisture content over which soil is plastic.

Liquidity index(LI): Liquidity index is the ratio of the differences between the natural moisture content and plastic limit Wn-PL to the plasticity index (PL).Mathematically liquidity index, LI=Wn-PL/PL

Relative consistency $(\mathbf{C r})$ : This is the ratio of the differences between liquid limit and natural moisture content, LL-Wn, to the plasticity index, (Pl). This helps in determining if the soil can be molded or not. If the Cr is less than zero, any process of remolding will transform the soil into thick, viscous slurry. If it is greater than zero, it means that the soil cannot be molded. Symbolically, $\mathrm{Cr}=\mathrm{LL}-\mathrm{Wn} / \mathrm{PL}$

Moisture content test: This test determines the water content of the soil $\backslash$.It is expressed as a percentage of the weight of water to the dry weight of the soil. A known weight of samples were taken out of the preserved samples from the field and weighed. The sample was oven dried at a temperature of about $110^{\circ} \mathrm{C}$ for about 24 hours. The sample was then reweighed and taken for calculation of the moisture content. Thus, moisture content, $\mathrm{W}=\mathrm{M}_{2}-\mathrm{M}_{3} / \mathrm{M}_{3}-\mathrm{M}_{1} * 100\left(\mathrm{Mg} / \mathrm{m}^{3}\right)$

$\mathrm{M}_{1}=$ Mass of container, $\mathrm{M}_{2}=$ mass of wet soil +container

$\mathrm{M}_{3}=$ mass of dry soil+container .It is expressed in percentage

Specific gravity test: This is the ratio between the density of a substance and the density of water at $4^{\circ} \mathrm{C}$. The specific gravity has no dimension. The specific gravity of water is 1 , and soil between 2.50 and 2.90 and that of silt between 2.70 and 2.90 .

Specific gravity, Gs $=\mathrm{M}_{2}-\mathrm{M}_{3} /\left(\mathrm{M}_{4}-\mathrm{M}_{3}\right)\left(\mathrm{M}_{2}-\mathrm{M}_{1}\right)$

$\mathrm{M}_{1}=$ Mass of conical flask, $\mathrm{M}_{2}=$ mass of conical and soil. $\mathrm{M}_{3}=$ mass of conical flask, soil and water $\mathrm{M}_{4}=$ mass of conical flask and water.

Permeability test: This is also called the hydraulic conductivity. It is the measure of the ability of water to flow through the soil. It is expressed in units of velocity, which is meter per seconds $(\mathrm{m} / \mathrm{s})$.Falling head permeameter apparatus was used for the test. The apparatus was used for the test . The apparatus used consist of burette, porous cover, screen soil sample tube, constant head chamber. Disturbed samples were compacted using the optimum moisture content determined from compaction test carried out earlier. The average of four compacted samples were taken and recorded. The samples were soaked in water for 48 hours and removed from water thereafter. The base of the mould was connected to the water reservoir and top connected to a calibrated glass stand pipe of known cross section area. The pipe was then filled with water. The water level in the stand pipe was allowed to fall continuously as water flows through the soil specimen. The time it took the water to flow from one height to another was noted.

Thus permeability $\mathrm{K}=2.303 \mathrm{al} / \mathrm{A}\left(\mathrm{t}_{1}-\mathrm{t}_{\mathrm{o}}\right) \log 10\left(\mathrm{~h}_{\mathrm{o}} / \mathrm{h}_{1}\right)$

$\mathrm{K}=$ permeability, $\mathrm{a}=$ cross section of stand pipe.

$\mathrm{L}$ and $\mathrm{A}=$ Length and area of cross section of the soil sample or mould, $\mathrm{t}_{\mathrm{o}}=$ initial time, $\mathrm{t}_{1}=$ final time, $\mathrm{h}_{\mathrm{o}}=$ initial height of water, $\mathrm{h}_{1}=$ final height of water.

\section{Discussion Of Results}

Geotechnical assessment of gully sites: Incipient gullies were observed in different parts of Mbaukwu, Awka south L.G.A of Anambra State. The locations of the gullies site are shown in Table 11 and the photographs of the gullies sites are also attached (plate 1 to 8 ).

Table IV: Location of the Gully Sites.

\begin{tabular}{|l|l|l|l|}
\hline Samples & Depth & Width & Boundary Between \\
\hline I & 2.0 & 7.0 & Ovollo-Akabor (O-A) \\
\hline II & 1.0 & 21.0 & Ovollo-Akabor (O-A) \\
\hline III & 2.5 & 35.0 & Ovollo-Akabor (O-A) \\
\hline IV & 35.0 & 20.0 & Ovollo-Akabor (O-A) \\
\hline V & 62.0 & 24.0 & Ovollo-Ogba (O-O) \\
\hline VI & 60.0 & 45.0 & Ovollo- Ogba (O-O) \\
\hline VII & 1.5 & 31.0 & Ovollo- Ogba (O-O) \\
\hline VIII & 1.0 & 15.0 & Ovollo- Ogba (O-O) \\
\hline
\end{tabular}


However, the depth of the incision of the gullies ranges from $1.0 \mathrm{~m}$ to $62.0 \mathrm{~m}$ with a mean value $20.63 \mathrm{~m}$, whereas the width of the gullies vary from $7.0 \mathrm{~m}$ to $45.0 \mathrm{~m}$ with an average of $24.75 \mathrm{~m}$. The general trending of these gully system are SE-NE and SW with the SE trend dominating. This indicates that the gullies in Mbaukwu are still very much in their early stage of development.

Table V: Summary of laboratory results for soils along Mbaukwu gullies.

\begin{tabular}{|c|c|c|c|c|c|c|c|c|c|}
\hline $\begin{array}{l}\text { GULLY } \\
\text { EROSION }\end{array}$ & $\begin{array}{c}(\mathbf{O}-\mathrm{A}) \\
1\end{array}$ & $\begin{array}{c}(\mathbf{O}-\mathrm{A}) \\
11\end{array}$ & $\begin{array}{c}(\mathrm{O}-\mathrm{A}) \\
111\end{array}$ & $\begin{array}{c}(\mathrm{O}-\mathrm{A}) \\
1 \mathrm{~V}\end{array}$ & $\begin{array}{c}(\mathrm{O}-\mathrm{O}) \\
\mathrm{V}\end{array}$ & $\begin{array}{c}\text { (O-O) } \\
\text { V1 }\end{array}$ & $\begin{array}{c}\text { (O-O) } \\
\text { VI1 }\end{array}$ & $\begin{array}{c}\text { (O-O) } \\
\text { VII1 }\end{array}$ & MEAN \\
\hline $\operatorname{Depth}(\mathrm{m})$ & 2.0 & 1.0 & 2.5 & 35.0 & 62 & 60 & 1.5 & 1.0 & 20.63 \\
\hline Width(m) & 7.0 & 21.0 & 35.0 & 20.0 & 24.0 & 45.0 & 31.0 & 15.0 & 24.75 \\
\hline Plastic limit (\%) & 19.0 & 20.0 & 22.0 & 28.1 & 20.1 & 24.0 & 18.5 & 17.5 & 21.15 \\
\hline Liquid limit (\%) & 34.0 & 35.0 & 42.0 & 46.0 & 32.0 & 34.5 & 32.0 & 32.1 & 35.95 \\
\hline $\begin{array}{l}\text { Plasticity index } \\
(\%)\end{array}$ & 15.0 & 15.0 & 20.0 & 17.9 & 11.9 & 10.5 & 13.5 & 14.6 & 14.80 \\
\hline $\begin{array}{l}\text { Optimum } \\
\text { Moisture content } \\
\text { OMC }(\%)\end{array}$ & 8.04 & 7.90 & 8.21 & 9.00 & 0.80 & 11.00 & 7.91 & 10.00 & 8.98 \\
\hline $\begin{array}{l}\text { Maximum Dry } \\
\text { Density MDO } \\
\left(\mathrm{MgLm}^{3}\right) \\
\end{array}$ & 2.021 & 2.810 & 2.040 & 3.910 & 2.062 & 2.001 & 2.801 & 2.311 & 2.49 \\
\hline $\begin{array}{l}\text { Uniformity } \\
\text { Coefficient }\end{array}$ & 0.425 & 0.370 & 0.501 & 0.430 & 0.549 & 0.379 & 0.351 & 0.301 & 0.413 \\
\hline $\begin{array}{l}\text { Coefficient of } \\
\text { curvature }\end{array}$ & 0.125 & 0.228 & 0.296 & 0.323 & 0.199 & 0.220 & 0.199 & 0.198 & 0.223 \\
\hline $\begin{array}{l}\text { Soil } \\
\text { classification/ } \\
\text { description }\end{array}$ & $\begin{array}{l}\text { Brown, } \\
\text { gravell } \\
\text { y, silty, } \\
\text { clayey } \\
\text { sand }\end{array}$ & $\begin{array}{l}\text { Brown, } \\
\text { gravell } \\
\text { y, silty, } \\
\text { clayey } \\
\text { sand }\end{array}$ & $\begin{array}{l}\text { Dark } \\
\text { brown, } \\
\text { gravelly, } \\
\text { silty, } \\
\text { clayey } \\
\text { sand }\end{array}$ & $\begin{array}{l}\text { Dark } \\
\text { brown, } \\
\text { gravelly, } \\
\text { silty, } \\
\text { clayey } \\
\text { sand }\end{array}$ & $\begin{array}{l}\text { Brown, } \\
\text { gravell } \\
\text { y, silty, } \\
\text { clayey } \\
\text { sand }\end{array}$ & $\begin{array}{l}\text { Brown, } \\
\text { gravelly, } \\
\text { silty, } \\
\text { clayey } \\
\text { sand }\end{array}$ & $\begin{array}{l}\text { Reddi } \\
\text { sh, } \\
\text { gravel } \\
\text { ly, } \\
\text { silty, } \\
\text { claye } \\
\text { y sand }\end{array}$ & $\begin{array}{l}\text { Reddi } \\
\text { sh,gra } \\
\text { velly, } \\
\text { silty,c } \\
\text { layey } \\
\text { sand }\end{array}$ & - \\
\hline Gravel \% & 3 & 3 & 3 & 4 & 2 & 3 & 1 & 1 & \\
\hline Sand \% & 76 & 78 & 79 & 69 & 85 & 79 & 75 & 71 & \\
\hline Silty + Clay \% & 21 & 19 & 18 & 27 & 13 & 19 & 24 & 28 & \\
\hline $\begin{array}{l}\text { Shrinkage } \\
\text { potential }\end{array}$ & Low & Low & Low & Low & Low & Low & Low & Low & \\
\hline Plasticity & Low & Low & $\begin{array}{l}\text { Intermed } \\
\text { iate }\end{array}$ & $\begin{array}{l}\text { Intermed } \\
\text { iate }\end{array}$ & $\begin{array}{l}\text { Interme } \\
\text { diate }\end{array}$ & $\begin{array}{l}\text { Intermed } \\
\text { iate }\end{array}$ & Low & Low & \\
\hline $\begin{array}{l}\text { BSCS } \\
\text { classification }\end{array}$ & SCL & SCL & SMI & SMI & SCL & SMI & SCL & SCL & \\
\hline
\end{tabular}

Meanwhile, it has been observed that the geotechnics of any research work determines its susceptibility (Onwuemesi, 1990). The geotechnical parameters of eight soil samples from eight gully sites in the study area at depths of $1.0 \mathrm{~m}$ and $62.0 \mathrm{~m}$ were analyzed using size analysis, Atterberg limit test, and compaction test.

The size analysis result (Table111) shows that sample I, II, V, VII and VIII are made up of sands with low clays, while sample III, IV and VI contain sands with intermediate contents of silt. The soils are generally not well sorted, thus do not behave well as drained material. This character makes its permeability not well improved and in turn can hardly increased incidence of water logging, surface run-off and erosion.

The microstructure of stand refers to its particle arrangement that in turn, involves its packing. The soil in the study areas is not well sorted and this implies that the particle size distribution does not extend over a wide range without excess deficiency in any particular size. This character makes the soils unsteady and has varying properties including strength, resistance to erosion and compatibility. This also explains the ease with which erosion occurs in the study area.

Atterberg limit test is an important soil test in environment and foundation studies. It gives an indication of the consistency limits of the soil. Sample III, IV and VI have a high plastic limit and liquid limit, though they all have intermediate plasticity. The large values of their plasticity index indicate that they are relatively stable over or wider range of moisture content compared to those of sample I, II, V, VII and VIII. The entire area has a low shrinkage potential or low shrinkage limit.

The compaction result shows that the maximum dry density (MDD) ranges as 2.001 to 3.910 with the mean value as 2.49. The optimum moisture content (OMC) range from 7.90 to 11.00 and has its mean value as 8.98. Sample VI has the lowest (MDD) while sample IV has the highest (MMD). Sample VII has the lowest (OMC), while sample VI has the highest (OMC). The low values of the (MDD) imply that the soil are generally not compacted and are loosely bound for the soil to be compacted, it must develop high ahead strength, low permeability and low water absorption and undergo minimal settlement especially for engineering purposes. 
Result of geotechnical investigation and laboratory analysis showed that the soil in the study areas is majorly sand; that are loosely bonded or loosely held together. They contain very small amount of clay which normally serves as a binding material. The three major clay minerals are illite, kaolinite, and montmorillonite and all there were discovered in the study area with variations in proportion. Actually, the type and nature of Ameki sand (the bedrock in the study area) to a large extent influence the soil upon it. It is easily eroded sand and is known to be very unstable. Therefore, once there is any runoff on the surface, there would be less resistance by the sand resulting in the intensity or ferocity of the gully erosion in the area.

Gullies in the study area are one that is so intense and can be tied to the character of the soil as shown in the analysis result (table 111). The soils show low to medium plasticity and grain sizes that are very fine and which can be easily washed off.

\section{Conclusion And Recommendations}

The engineering aspect of soil erosion control should be geared towards changing the slope characteristics of the area so that the amount and velocity of run-off are decreased. Other soil stabilization techniques such as grouting, dewatering and construction of concrete ripraps should be applied where pore pressures and seepage force are high.

Agro-forestry methods such as planting of trees like bamboo and grasses to forestall eliminate or check the development of erosion in the area should be encouraged. Also trees like Gmelinaarborea, Pinuscarihacea, Dacroydesedulus, Cassis nidosa, Traculia Africana and hvingiagobonensis which have high rate of survival are recommended for erosion control in the study areas. These will intercept raindrops and decrease the speed with which they hit the unconsolidated earth.

Other agricultural practices that tend to stripe off the protective vegetation cover of the soil like bushburning, overgrazing, over-cultivation and deforestation should be discouraged.

As much as possible, government should enact policies to prevent people from doing anything that will aggravate the already non-compactable Mbaukwu soil as soon as any sheet erosion is discovered. It should be bulldozed. Proper drainage channels should be put in place in both the study areas and the whole of Anambra State while geotechnical evaluation is carried out on the soil from time to time to assess changes in the soil and the environment.

Finally, the investigation provides the geotechnical characteristics of the soils of the study area.

\section{References}

[1]. British Standard Code of Practice for Site Investigation, 1981. Published by the British Standards Institution, pp. 1-200.

[2]. Canter, L. W. (2004), Environmental Department of Natural Resources and water. Fact sheets L81 pp. 1-4.

[3]. Egboka, B. C. E. and Okpoko, E. L, 1984, Gully Erosion in the Agulu-Nanka Region of Anambra State, Nigeria; in Wallings, D. E., S. S. D. Foster and P. wuzek (eds). Challenges in African Hydrology and Water Resources, IAHS publ, no. 144, pp. 334-344.

[4]. Nwajide, C. S. 2003, Geology of Nigeria's Sedimentary Basins. CSS Bookshops, Lagos, Nigeria. 564p.

[5]. Nwajide, C. S. and Hoque, M; 1979, 'Gullying Processes in South-Eastern Nigeria', The Nigerian Field XLIV, No 2, 64-74.

[6]. Ofomata, G. E. K; 1965, Factors of Soil Erosion in the Enugu Area of the Nigeria; Nigerian Geogr Jour. 8, 45-59.

[7]. Onuoha, K. M. and Uma, K. O; 2008, Hydrodynamic flow and formation Pressures in the Anambra Basin, Southern Nigeria, Product of University of Nigeria, Nsukka Virtual Library, pp. 142-159.

[8]. Onwuemesi, A. G., 1990, Hydrogeophysical and Geotechnical Investigation of the Ajali Sandstone in Nsukka and Environs with reference to groundwater resources and gully erosion problems. Water Res J Nig. Assoc. Hydrogeol, 2(1).

[9]. Trunswell, J. F. and Cope, R. N, 1963; The Geology of parts of Niger and Zaria Province, Northern Nigeria. Bulletin no. 29. Published by the Geological Survey of Nigeria.

[10]. Uma, K. O. and Onuoha, K. M; 1987, 'Groundwater Fluxes and Gully Development in S E Nigeria, Earth Evolution Sciences. 


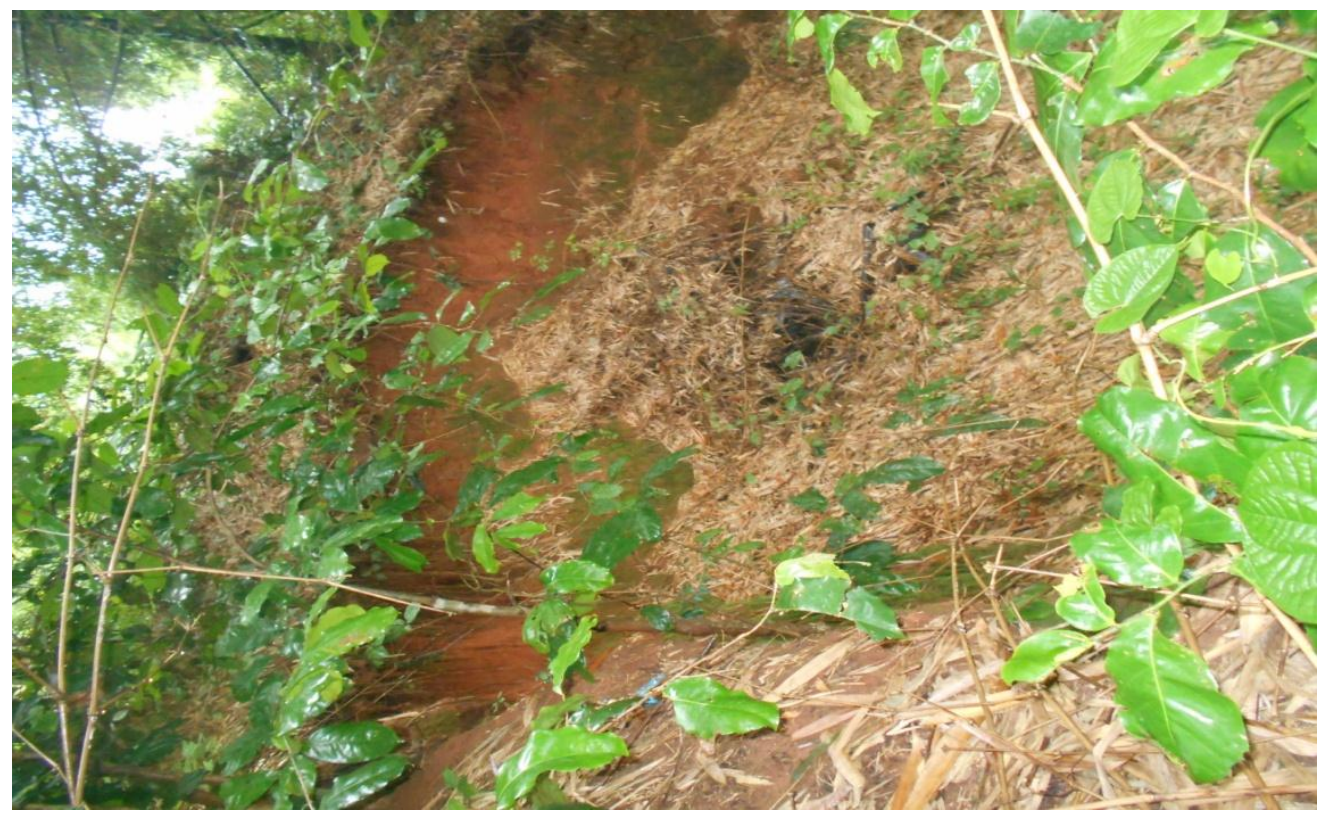

PICTURE 1: Gully prevention using vegetation.

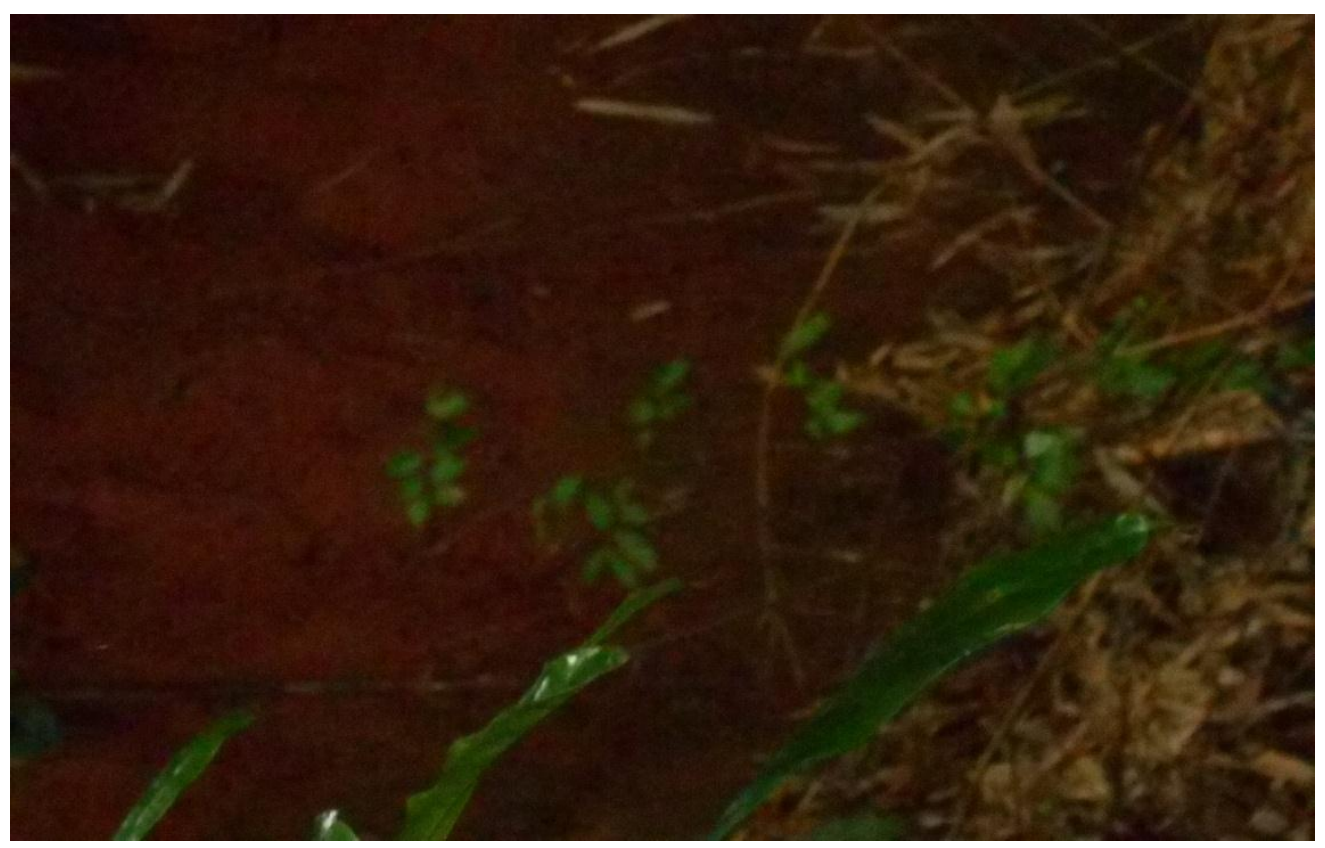

PICTURE 2: Active gully at one of the site. 


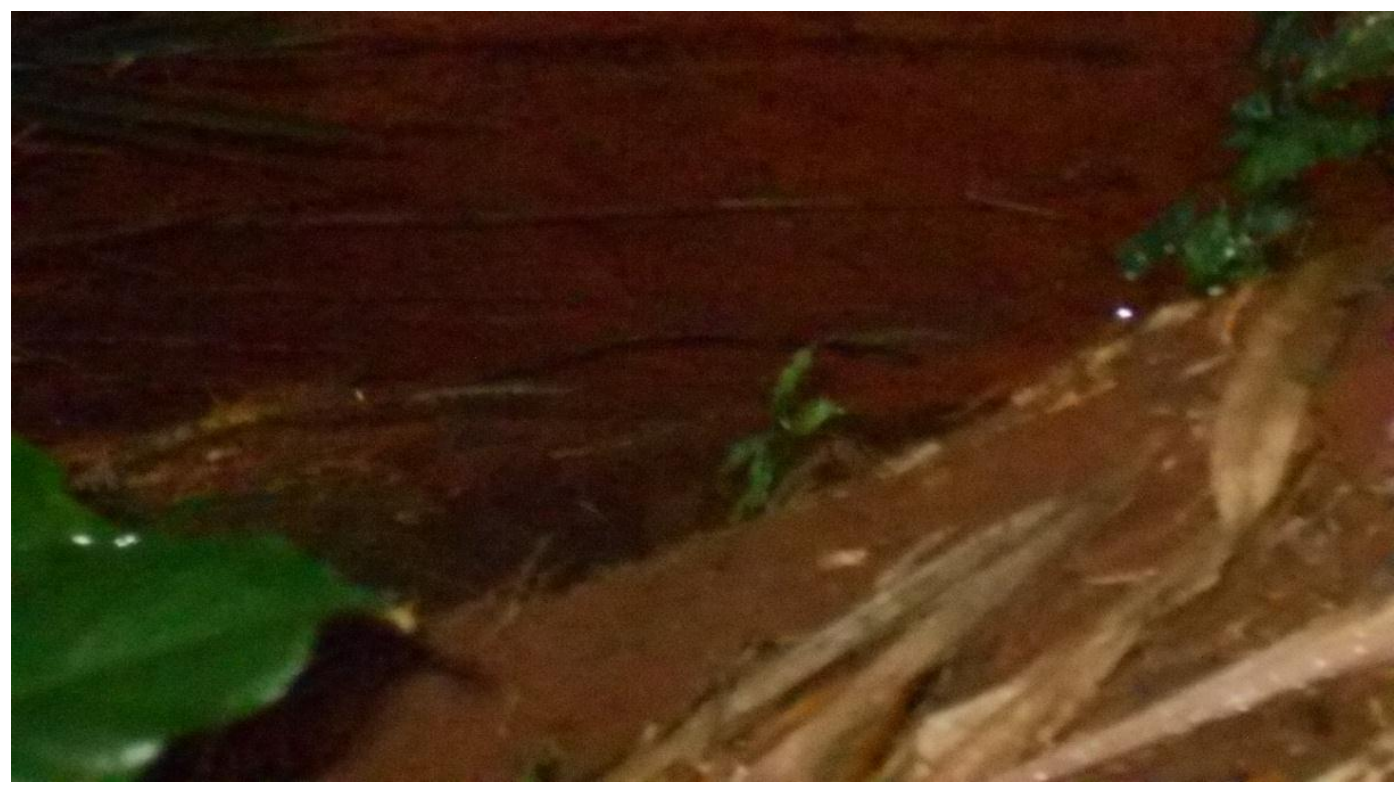

PICTURE 3: Active gully that collect the running water.

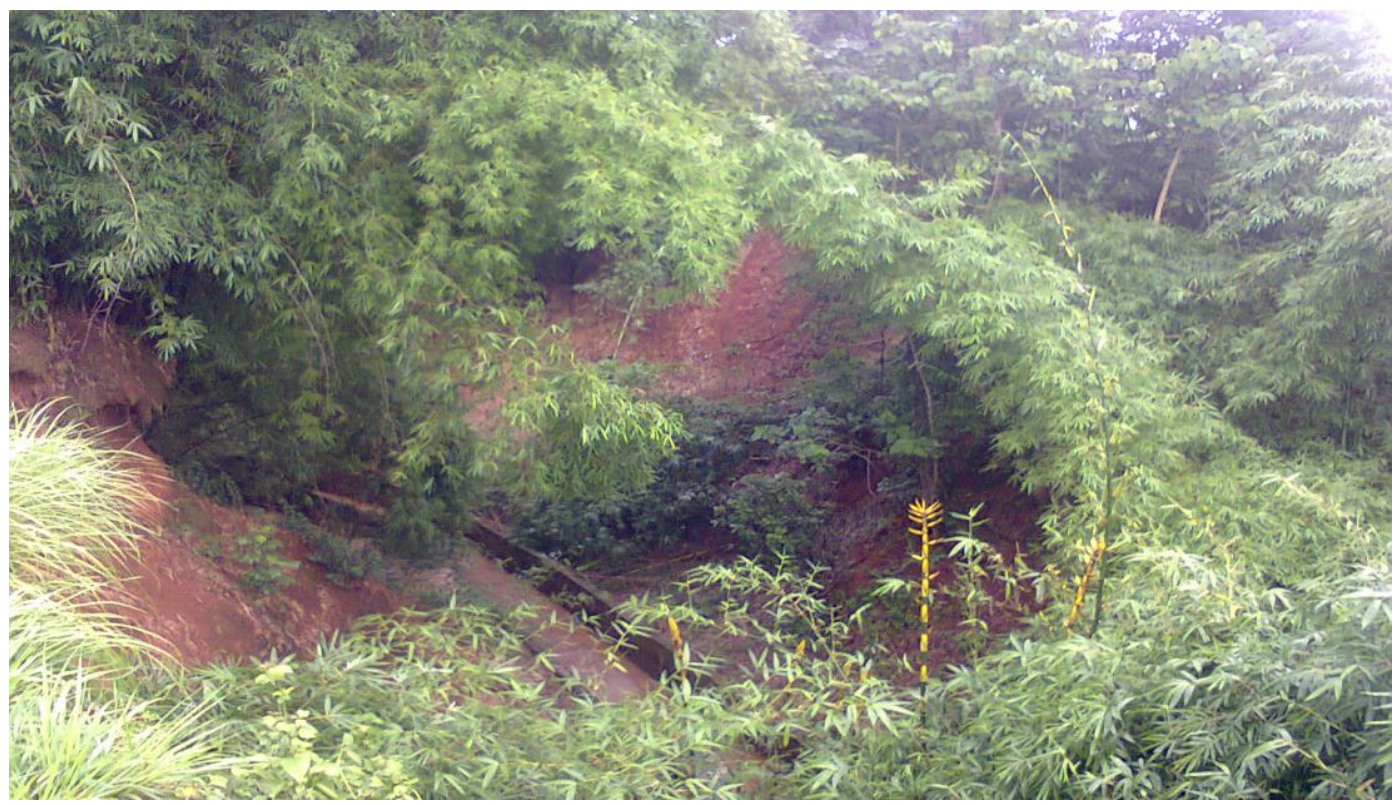

PICTURE 4: Gully site with good drainage system and vegetation. 
Geotechnical Investigation of Soil around Mbaukwu Gully Erosion Sites, South-Eastern Part .....

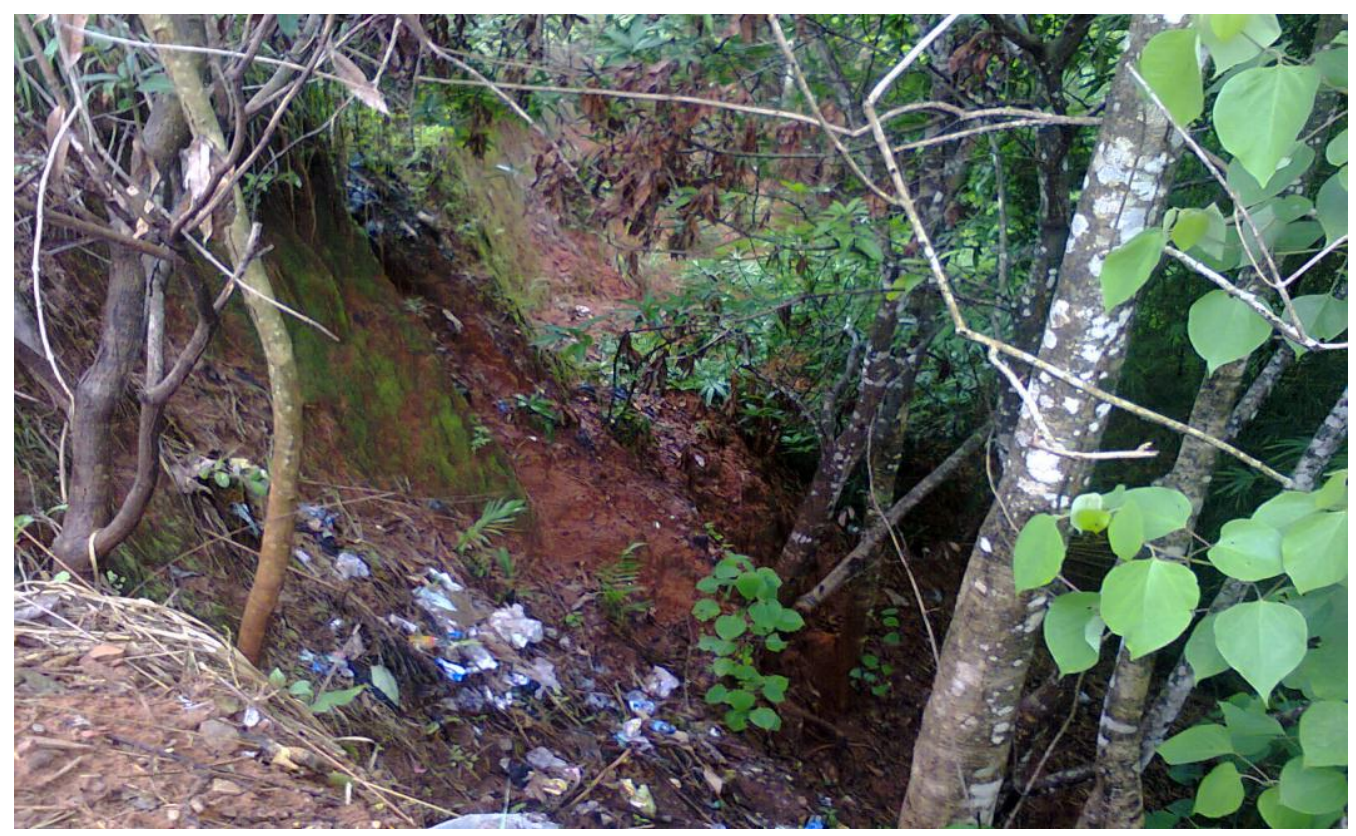

PICTURE 5: Refuge dump along gully site.

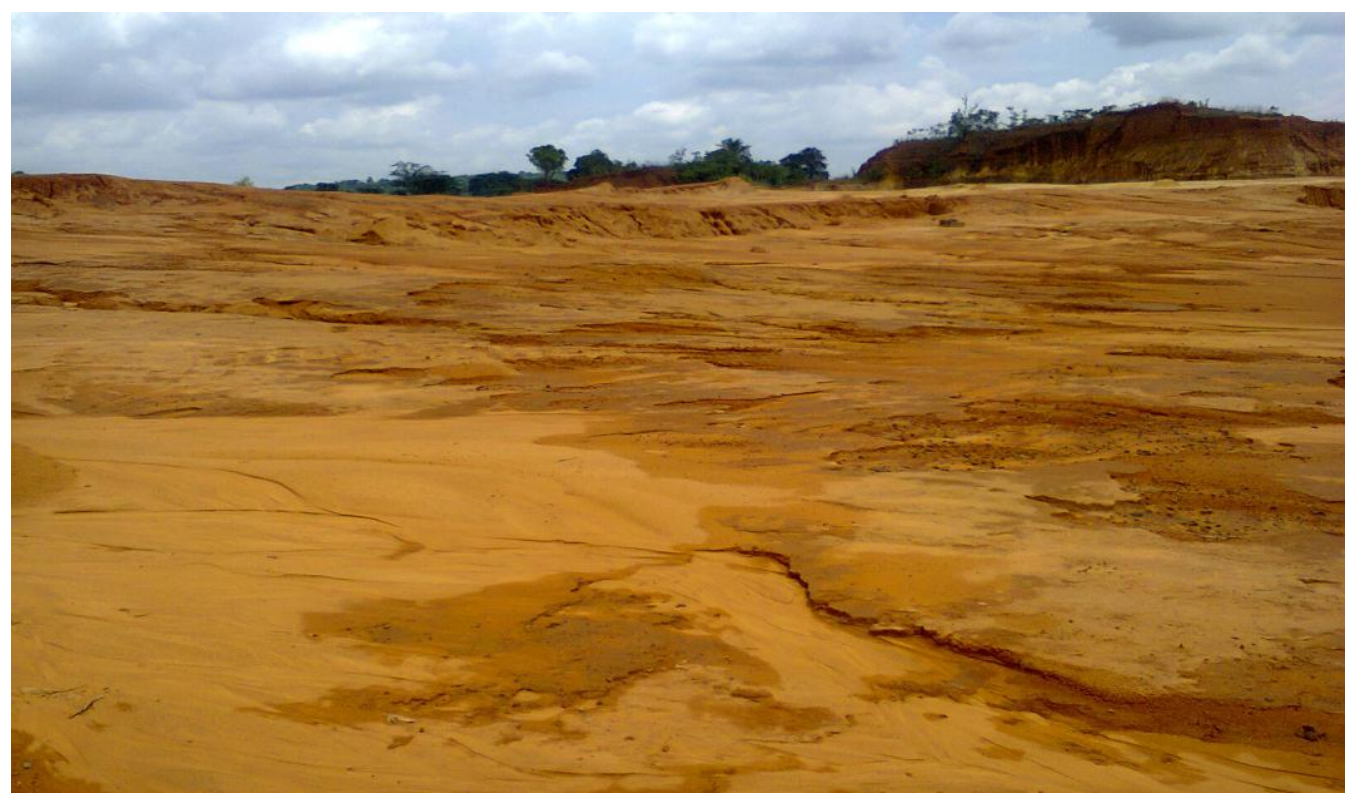

PICTURE 6: Onset of gully triggered by deforestation and topsoil excavation. 


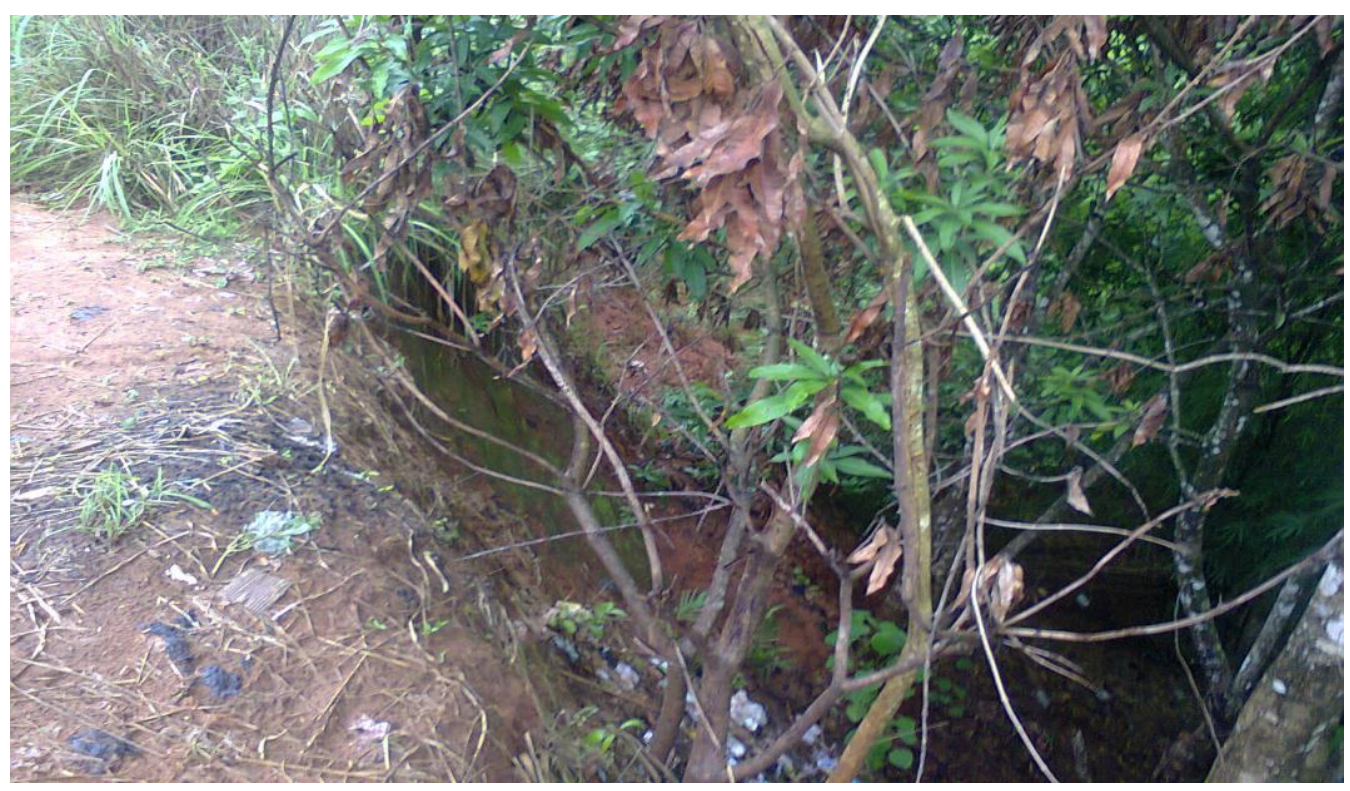

PICTURE 7: Inactive gully site with vegetation.

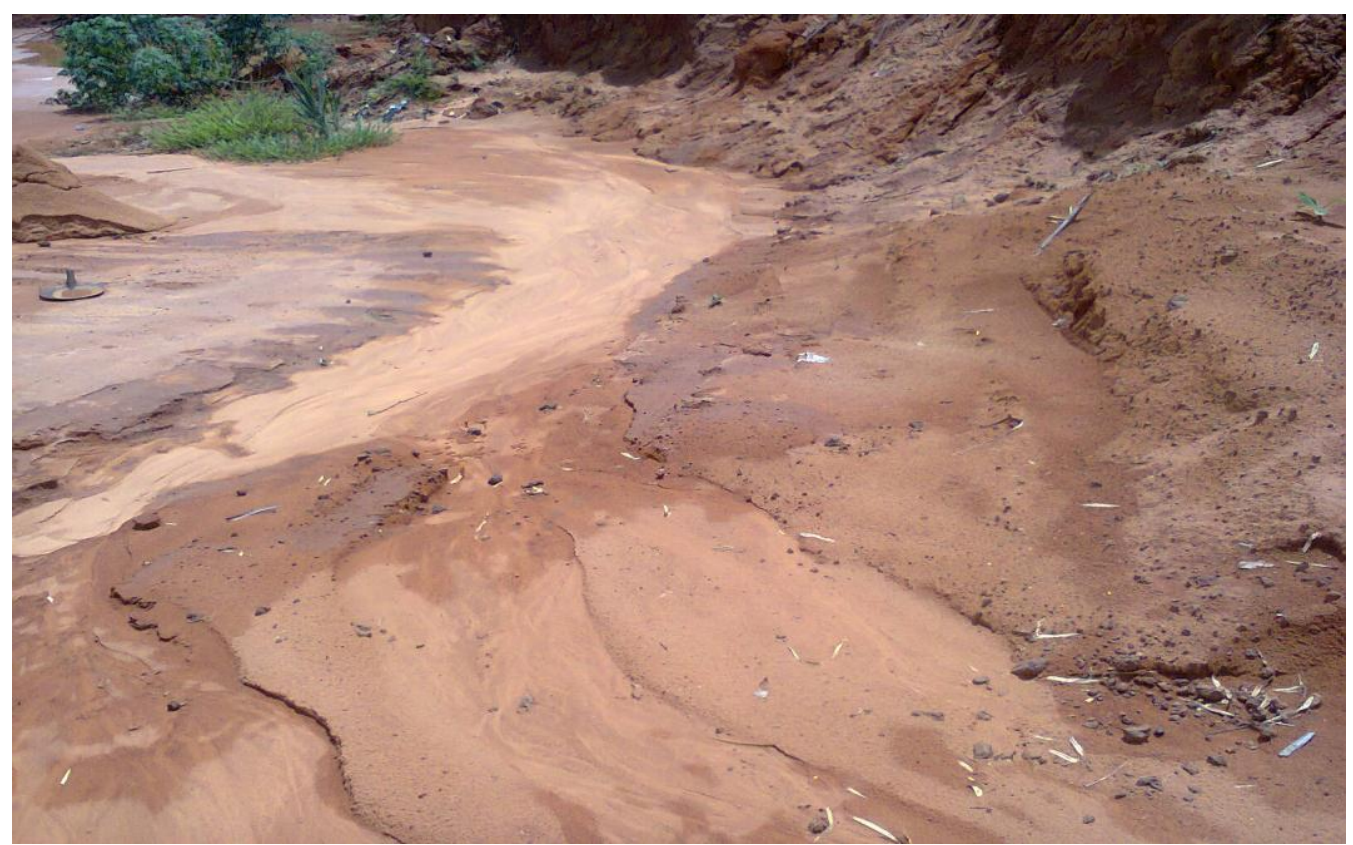

PICTURE 8: Gateway to the gully site without drainage system. 